\title{
Zirconium Alloys for Fuel Element Structures
}

\author{
Gerhard Bart and Johannes Bertsch
}

\begin{abstract}
Today more than 400 light water power reactors (LWRs) operate worldwide providing approximately $17 \%$ of the world's electricity demand. One important component for their successful operation is the fuel tube, made out of a zirconium alloy. A huge number of out-of-pile and in-pile experiments have been performed to improve step by step the fuel for higher burn-up and to reduce the failure rates of fuel pins close to zero. The influencing parameters for excellent or poor cladding behaviour are numerous and sometimes counteract each other. The process of cladding corrosion is slow, difficult to follow, the mechanistic understanding at best incomplete. A vast amount of literature documents the abundant tests and comes up with hypotheses and models for the materials behaviour. PSI has supported for the past 20 years the development of high burn-up fuel cladding by microstructural research studies and service work in post-irradiation examination of test pins. This article reviews the development of the cladding tubes, focussing on the chemical and materials science aspects.
\end{abstract}

Keywords: Cladding corrosion. Fuel behaviour. LWR

\section{Introduction}

The environmental conditions for structural materials in light water reactor cores are harsh. The cooling water temperature is around $300{ }^{\circ} \mathrm{C}$. Water flow velocities are in the range of $2-5 \mathrm{~m} / \mathrm{s}$ and can lead to vibrations of individual fuel rods in the fuel bundles. The neutron flux is in the range of $5 E 13 / \mathrm{cm}^{2}$ s. Each fast neutron from uranium fission slows down in a cascade process which leads to several hundred displaced atoms in the metallic lattice (each fission provides some $200 \mathrm{MeV}$ of ultimately heat energy and 2-3 new neutrons). Due to the intense radiation field of neutrons, electrons

${ }^{\star}$ Correspondence: Dr. G. Bart

Labor für Werkstoffverhalten (LWV)

Forschungsbereich Nukleare Energie und Sicherheit

(NES)

Paul Scherrer Institut (PSI)

$\mathrm{CH}-5232$ Villigen PSI

Tel.: +41563102210

Fax: +41563102203

E-Mail: gerhard.bart@psi.ch and gamma rays from beta decays of fission products, the water is strongly radiolyzed showing high concentrations of $\mathrm{H}_{2} \mathrm{O}_{2}, \mathrm{OH}$, $\mathrm{H}_{3} \mathrm{O}^{+}$, and $\mathrm{e}^{-}$. The options for selecting suitable metallic materials to withstand such conditions are small, even more so, if the material has to be ductile, have high mechanical strength, be geometrically stable during irradiation and should not parasitically absorb a lot of neutrons, leading possibly by itself to long-lived gamma-emitting radioisotopes of waste.

For light water reactors the choice for fuel element components (fuel tubes and spacer grids, holding the fuel pins together in a fuel element) was zirconium metal with physicochemical parameters as indicated in
Table 1 [1]. The $4 \mathrm{~m}$ long fuel pin (diameter $\sim 10 \mathrm{~mm}$, wall thickness $\sim 0.65 \mathrm{~mm}$ ) containing the $\mathrm{UO}_{2}$ fuel pellets has to be leak tight and constitutes an important barrier against spread of radionuclides within the reactor system and beyond. It should also survive in the presence of steam at $900-1200{ }^{\circ} \mathrm{C}$ for several minutes under hypothetical loss of coolant accident conditions.

The typical damage rate of such fuel tubes in today's reactors lies at $1-5$ defects per one million pins, irradiated for 4-5 years to a fuel burn-up of $\sim 50 \mathrm{MWd} / \mathrm{kg}$ H.M. (Megawatt days per kg of heavy metals, consisting of uranium and plutonium).

The $50 \mathrm{MWd} / \mathrm{kg}$ (approximately half the energy extracted from one fuel pin) corre-

Table 1. Physical properties of Zirc- alloys (Zirc-2 and Zirc-4) [1]

\begin{tabular}{|c|c|c|c|c|}
\hline & Unit & Average & $\begin{array}{l}\text { [11 20] } \\
\text { direction }\end{array}$ & $\begin{array}{l}{[0001]} \\
\text { direction }\end{array}$ \\
\hline Specific mass & $\mathrm{Kg} \mathrm{m}^{-3}$ & 6,500 & & \\
\hline Thermal expansion & $\mathrm{K}^{-1}$ & $6.7 \times 10^{-6}$ & $5.2 \times 10^{-6}$ & $10.4 \times 10^{-6}$ \\
\hline Young's Modulus & $\mathrm{GPa}$ & & 99 & 125 \\
\hline Lattice parameter & $\mathrm{nm}$ & & $\mathbf{a}=0.323$ & $\mathbf{c}=0.515$ \\
\hline Elastical limit recrist & (MPa) & $200-250$ & & \\
\hline Thermal conductivity & $\mathrm{W} \cdot \mathrm{m}^{-1} \cdot \mathrm{K}^{-1}$ & 22 & & \\
\hline Specific heat capacity & $\mathrm{J} \cdot \mathrm{kg}^{-1} \cdot \mathrm{K}^{-1}$ & 276 & & \\
\hline $\begin{array}{l}\text { Thermal neutron capture } \\
\text { cross section }\end{array}$ & barn $\left(10^{-28} \mathrm{~m}^{2}\right)$ & 0.185 & & \\
\hline
\end{tabular}


sponds to an equivalent amount of 110'000 $\mathrm{kg}$ of fossil fuel. Twenty years ago the average discharge fuel burn-up was only around $30 \mathrm{MWd} / \mathrm{kg}$ but also the volumetric power in the fuel elements and the speed for power transients during reactor operation has been increased since. Such an increase was only possible with systematically improved fuel element structures. The driving force to strive for higher burn-ups clearly lies in reducing fuel cycle costs and volumes of highly radioactive fuel waste.

The application of zirconium alloys as fuel tubes for LWRs is a success story. Many difficulties had to be overcome though and in Switzerland the high-power reactors Gösgen (KKG, a Framatome-Siemens pressurized water reactor) and Leibstadt (KKL, a General Electric boiling water reactor) together with the fuel vendors and Paul Scherrer Institute have strongly supported the development of improved fuel tube structures for high burn-up. We want to stress that this development was only possible with a critically but constructively acting Swiss nuclear safety inspectorate.

\section{Zirconium Fuel Pin Manufacturing}

Some important hurdles to overcome in the zirconium industry were firstly the metal extraction from $\mathrm{Zr}$-silicate ore, called zircon. As shown in the flow sheet (Fig. 1), zirconium/hafnium and silicon are first separated from impurities by carbothermic reaction, leading to ( $\mathrm{Zr}, \mathrm{Hf}) \mathrm{C}$ and $\mathrm{SiC}$. During the subsequent chlorination at $1200{ }^{\circ} \mathrm{C}$ and fractionated condensation, $(\mathrm{Zr}, \mathrm{Hf}) \mathrm{Cl}_{4}$ is separated from $\mathrm{SiCl}_{4}$. $\mathrm{Zr}$ is then isolated from Hf (its IVa-group sibling with equal valence electron configuration and chemical affinity, which has a very large neutron activation cross section!) by sublimation. Finally $\mathrm{Zr}$ is reduced by $\mathrm{Mg}$ in the so-called Kroll process.

Pure zirconium metal is very ductile and does not show the necessary strength and corrosion resistance. The addition of $1.5 \%$ of tin and a small amount of oxygen led to a solid solution of much higher strength, but the corrosion resistance of the product was still weak. By mistake (and chance) during tests in the 1950s a small piece of stainless steel was melted together with the above-mentioned zirconium-siliconoxygen alloy, which resulted in a much improved corrosion resistant alloy. $\mathrm{Fe}, \mathrm{Cr}$, and $\mathrm{Ni}$ from the stainless steel are soluble in a zirconium melt and in the high-temperature $\beta$-zirconium allotropic form but precipitate into Laves phase $\mathrm{Zr}(\mathrm{Fe}, \mathrm{Cr})_{2}$ and $\mathrm{Zr}_{2}(\mathrm{Fe}, \mathrm{Ni})$ secondary particles when cooled below $\sim 860^{\circ} \mathrm{C}$ to the low temperature $\alpha$-form.

Several important challenges consisted in optimizing the thermo-mechanical tube production process:

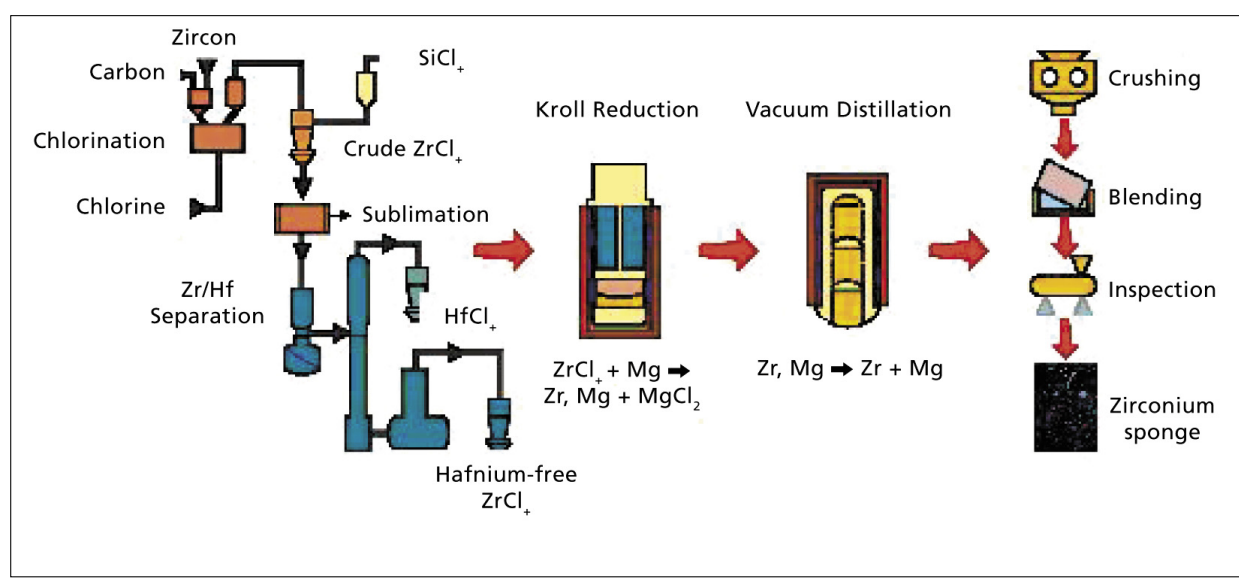

Fig. 1. Flow chart of zirconium extraction process from zircon ore [2]. Courtesy of CEZUS, Ugine, France.
- Depending on the applied cold-rolling steps the texture of the hexagonal metallic lattice, being a result of preferred dislocation movement along favoured crystal planes, varies significantly (Fig. 2 ). The resulting texture strongly influences the in-pile thermal and radiation induced tube creep and growth.

- Due to the anisotropic hexagonal crystal (the thermal expansion coefficient in the $a$-direction being different from the one in the $c$-direction) there are always significant internal stresses in a tube, primarily arising from cold work. Even after thermal stress relief annealing, some stress builds up again during cooling. Depending on the internal stress fields, crystal orientation and texture, brittle hydrides, which form during reactor irradiation, are precipitated in a more or less advantageous form as will be shown later.

- Finally, the above-mentioned secondary phase particles precipitate in larger or smaller size depending on the thermomechanical process (T-levels, fast or slow cooling), which has a strong impact on the corrosion resistance.

So the whole tube manufacturing process (extraction to reach the targeted tube dimensions under optimization of the texture, adding intermediate heating steps for stress relief or full re-crystallisation, quenching for Laves phase particle size optimization) is very elaborate. The companies take a lot the highly competitive $6-10$ billion $\mathrm{CHF} /$ year fuel market. A diagram showing the complexity of the fuel tube manufacturing process, its influence on the tube material properties and on in reactor performance criteria is depicted in Fig. 3 [4].

\section{Corrosion Process of Zirconium Alloys}

Zirconium is electrochemically unstable and oxidizes to $\mathrm{ZrO}_{2}$, protecting itself at ambient temperature against further oxidation by a passive, a few nm thick oxide layer. With increasing temperature, corroof care of their manufacturing know-how in

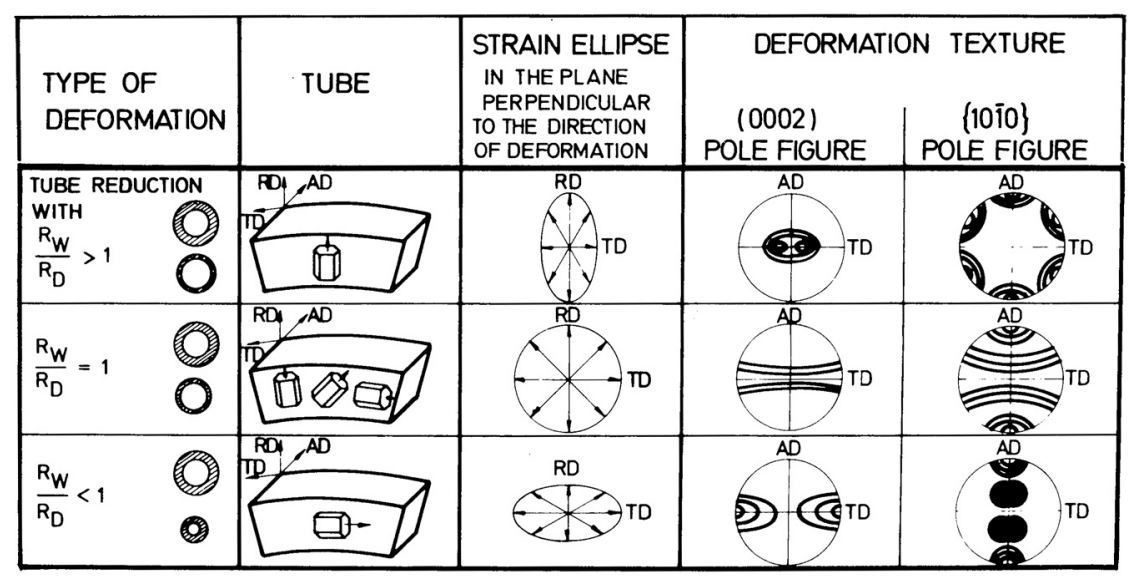

Fig. 2. Texture development in Zirc fuel tubes depending on thermo-mechanical process variations in tube extraction [3]. Courtesy of ASTM, West Conshohocken PA, USA. 


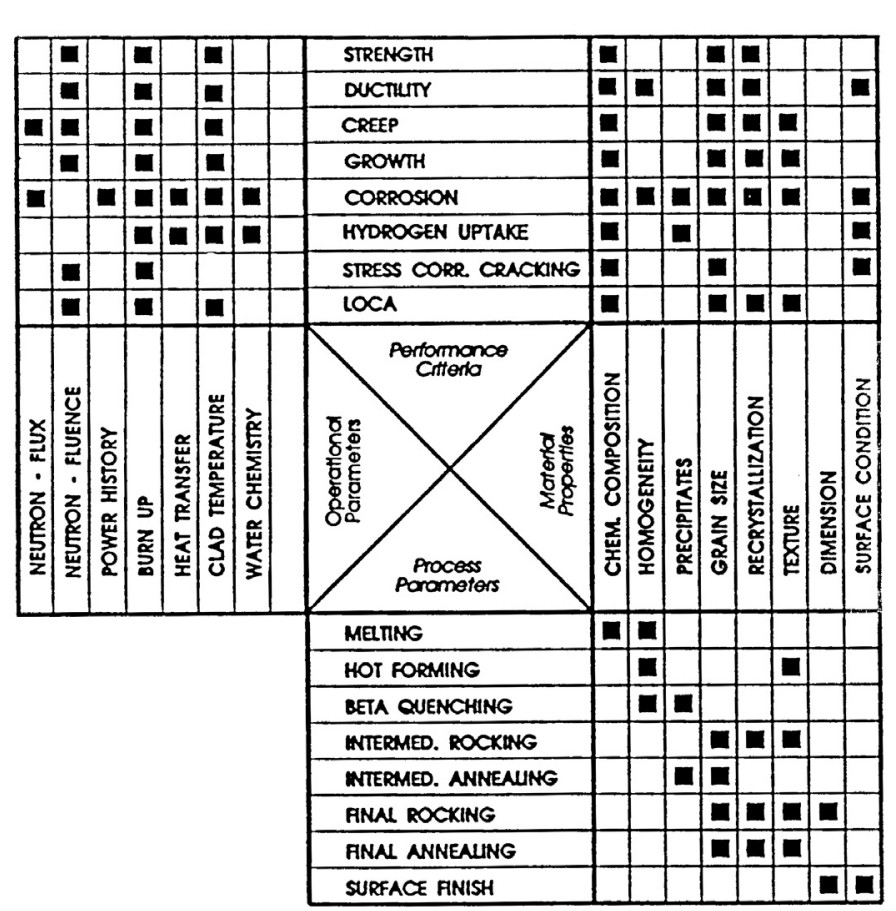

Fig. 3. Interaction of reactor operating parameters, fuel tube materialsand fabrication process parameters on fuel tube performance criteria [4]. Courtesy of ANS, La Grange Park, Illinois, USA.

sion speeds up and beyond $\sim 1500{ }^{\circ} \mathrm{C}$ zirconium burns under atmospheric conditions in an exothermic runaway reaction.

No evidence has been found for $\mathrm{Zr}$ ion diffusion from the metal-oxide interface through the growing oxide layer to the oxidewater interface at $300{ }^{\circ} \mathrm{C}$ [5]. As only anion diffusion has been detected it is assumed that only oxygen lattice vacancies $\left(\square^{0}\right)$ and electrons are the mobile species in the $\mathrm{ZrO}_{2}$ lattice supporting further oxidation and it has to be assumed that local electric fields across the oxide layer play an important role for oxidation. The overall electrochemical corrosion reaction of zirconium

$\mathrm{Zr}+2 \mathrm{H}_{2} \mathrm{O} \rightarrow \mathrm{ZrO}_{2}+4 \mathrm{H}$

can be split into the following two half cell reactions [6]:

$\mathrm{Zr}+2 \mathrm{O}^{2-} \rightarrow \mathrm{ZrO}_{2}+2 \square^{0}+4 \mathrm{e}^{-}$

anodic half cell

$2 \square^{0}+2 \mathrm{H}_{2} \mathrm{O} \rightarrow 2 \mathrm{O}^{2-}+4 \mathrm{H}^{+}$

cathodic half cell: - water dissociation

$4 \mathrm{H}^{+}+4 \mathrm{e}^{-} \rightarrow 4 \mathrm{H}^{\cdot}$

cathodic half cell: - proton discharge step

Two oxygen anions of the $\mathrm{ZrO}_{2}$ lattice react with a new $\mathrm{Zr}$ metal atom at the metal-oxide interface (1), leaving behind two oxygen lattice vacancies which will diffuse outwards through the formed oxide layer along the $\mathrm{ZrO}_{2}$ crystallite grain boundaries until they reach water molecules somewhere at the oxide-water interface which they can dissociate (2). The electrons migrate outwards via electrically conducting sites (probably connected to the aforementioned small secondary phase particles $\left(\mathrm{Zr}(\mathrm{Fe}, \mathrm{Cr})_{2}\right)$, until they can discharge a hydrogen proton (3).

The diffusion-controlled oxidation curve flattens with increasing oxide thickness up to about 2-3 $\mu \mathrm{m}$, reached in a reactor after $\sim 100$ days. Then the corrosion proceeds more or less linearly with time for 600-900 days until a secondary transition point is reached which is characterized by an exponential corrosion rate increase. The tiny oxide crystals have a considerably smaller density and thus a larger specific volume than the corroding metal itself. This leads to a significant compressive stress in the oxide estimated in the order of $\sim \mathrm{GPa}$ and, at the mentioned thickness of 2-3 $\mu \mathrm{m}$, leads to oxide breakdown with pore formation. Several autoclave tests have indicated a cyclic growth pattern and very recent mi-
cro-X-ray-diffraction results seem to support a sequential growth of the thin innermost protective oxide layer [7]. The lattice pores thus formed are probably water-filled and then the further oxidation proceeds linearly with time as indicated. Nevertheless the post-transition corrosion process varies significantly with alloy make-up, differs strongly between boiling water- and pressurized water reactor conditions and is still hardly understood. Despite this, major improvements have been achieved, altering empirically in small steps the chemical composition and thermo-mechanical process, allowing today much higher burn-ups at modest corrosion rates.

In the reactor, the intense flux of fast neutrons gives rise to the production of interstitials (atoms which have been thrown out of their lattice position) and vacancies (where the atoms have been thrown out) in the fuel tube cladding. The interstitials and vacancies diffuse with different speed to sinks such as grain boundaries and dislocations or coagulate and form dislocation loops. The net effect of these defects is an increased electrical conductivity in the protecting $\mathrm{ZrO}_{2}$-layer and hence an increased corrosion rate compared to out-of-pile autoclave corrosion. In the underlying metal, neutron damage supports $\mathrm{Fe}$ diffusion out of the secondary phase precipitates and to their dissolution [8][9]. This process later in the lifespan of a fuel pin strongly increases the corrosion rate indicated by the mentioned second transition point. The radiation-induced dislocation loops within the metallic lattice lead to a strongly increased mechanical strength but simultaneously to a reduced ductility. Summing up the radiation effects on the cladding it is amazing to realize that each lattice atom is displaced about 15 times during the reactor exposure.

\section{Development of Today's Fuel Tube Alloys for PWRs and BWRs}

As indicated earlier, the accidentally added stainless steel to an early zirconium alloy melt proved very advantageous and has lead to the zircaloy (Zirc) specifications as noted in Table 2.

Table 2. Elemental composition of standard- and advanced LWR fuel cladding alloys [6]

$\begin{array}{lcccccc}\text { Element } & \text { M5 } & \text { E110 } & \text { E635 } & \text { Zirlo } & \text { Zirc-2 } & \text { Zirc-4 } \\ \text { Sn w/o } & 0 & 0 & 1.2 & 1.0 & 1.3-1.5 & 1.3 \\ \mathrm{Nb} \text { w/o } & 1.0 & 1.0 & 1.2 & 1 & 0 & 0 \\ \mathrm{O}, \mathrm{ppm} & 1000-1600 & 600-1000 & 500 & \sim 1100 & 1300 & 1300 \\ \mathrm{Fe}, \mathrm{ppm} & 500-700 & 100-300 & 3500 & 1000 & 1400-1800 & 2000 \\ \mathrm{Cr}, \mathrm{ppm} & ? & ? & 30 & 80 & 1000-1200 & 1000 \\ \mathrm{Ni}, \mathrm{ppm} & - & - & - & - & 500-800 & -\end{array}$




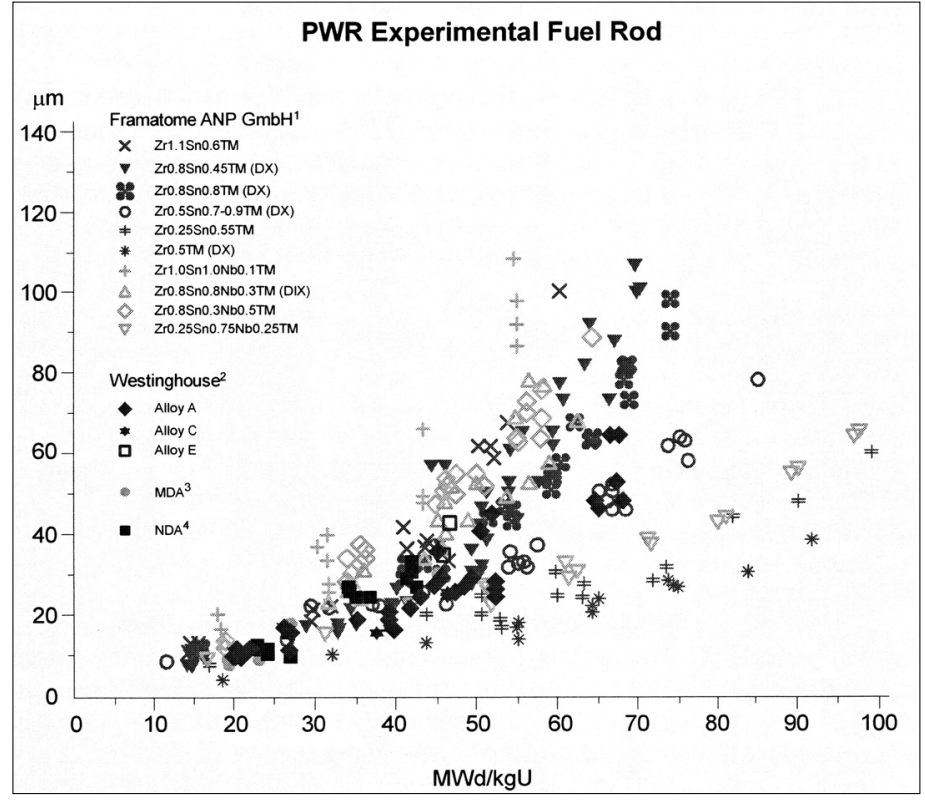

Fig. 4. Comparison of corrosion resistance of various advanced PWR fuel cladding tubes (the Framatome-ANP results were analyzed on fuel tubes from nuclear power plant Gösgen) [6]. Courtesy of ANT International, Surahammar, Sweden.

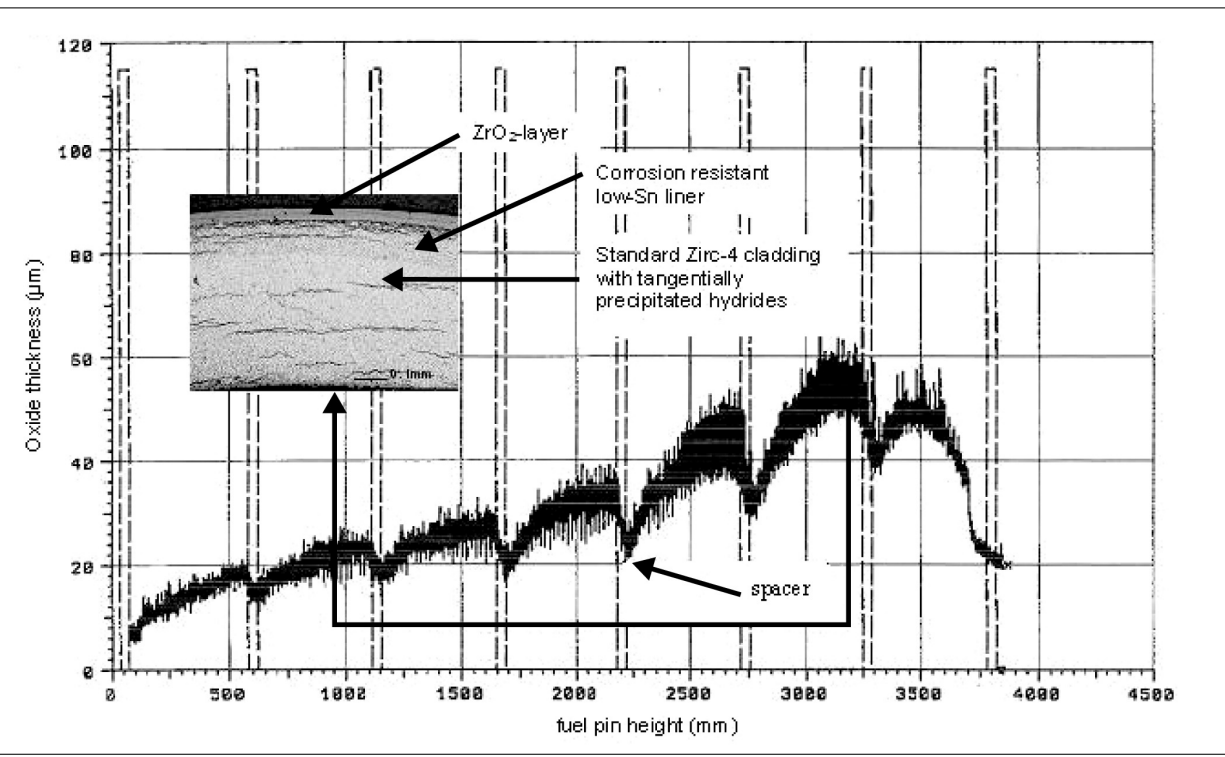

Fig. 5. Zirconium-oxide thickness profile of advanced Framatome-ANP Duplex-PWR cladding, irradiated at Gösgen power plant, characterized after irradiation at PSI. A corrosion resistant outer metal liner has been processed onto a base Zry-4 tube body. The oxide thickness increases from bottom to top of the fuel pin, showing distinct minima at spacer positions.

Zircaloy-4 is used in the hydrogen-rich, electrochemically reducing conditions of PWRs. As Ni supports unwanted hydrogen uptake in the metal, Zirc-4 has no Ni addition. After about three yearly operating cycles Zirc-4 shows 60-100 $\mu \mathrm{m}$ oxide thickness. The fuel with a $0.65 \mathrm{~mm}$ thick standard PWR-Zirc-4 cladding and a burn-up of $\sim 30-35 \mathrm{MWd} / \mathrm{kg}$ has then to be unloaded for safety reasons. As thorough safety-oriented experiments have shown, fuel with $>100 \mu \mathrm{m}$ oxide layer would possibly not survive controllably under hypothetical loss of coolant accident conditions. The reader should also keep in mind that corrosion is a statistical effect and that there are always some local environmental differences for individual fuel tubes (due to differences in heat flux, variations in surface deposits being heat transfer barriers ...) leading to variations in oxide thickness.

In order to increase the burn-up for PWRs, new cladding variants have been tested intensely with a lead at KKG (Kernkraftwerk Gösgen) in Switzerland together with the respective fuel vendor (Framatome-ANP, Erlangen, Germany) as depicted in Fig. 4. Promising test fuel pins resulting from such campaigns have then been shipped to PSI, where they were carefully analyzed with respect to corrosion, creep, growth, oxide spalling, ductility and hydriding. As a typical result of such tests Fig. 5 shows the axial oxide profile of a $4 \mathrm{~m}$ long pin, and a metallographic tube wall cross section at the site of maximum ox- ide thickness. New cladding variants with lowered tin concentrations and with added $1-2.5 \%$ of niobium have been found from such programmes worldwide, which corrode less and allow today nearly twice the burn-up (Fig. 6).

Why some of these $\mathrm{Zr}-\mathrm{Nb}$ alloys (depending strongly on the thermo-mechanical manufacturing treatment!) corrode much less than the earlier applied Zirc-4 tubes is still under investigation. Detailed microstructural and micro-chemical analyses performed at PSI (Fig. 7) with transmission electron microscopy, viewing at the metal oxide interface of two alloys, have shown that the diffusion profile of oxygen and the morphology of the boundary at the metaloxide interface in $\mathrm{Zr}(\mathrm{Nb})$ differ strongly from Zirc-4 [10]. The corrugated boundary of the $\mathrm{Zr}$-Nb specimen possibly reduces the stress field. At even higher magnification the atomic structure at the boundary revealed a direct transition from the hexagonal metallic lattice to the monoclinic oxide lattice (Fig. 7 inset) and absence of speculated amorphous interlayers. Such analyses help to experimentally support or disprove mechanistic assumptions about the corrosion process.

Zircaloy-2 which includes nickel is applied under the oxidizing conditions of BWR water chemistry (normal water chemistry as compared to newly applied hydrogen water chemistry). The boiling temperature of BWRs (slightly below 300 ${ }^{\circ} \mathrm{C}$ at $7 \mathrm{MPa}$ pressure) being approximately $30-40{ }^{\circ} \mathrm{C}$ lower than the exit temperature of the PWRs (operating at $14 \mathrm{MPa}$ ), typically leads to 3-4 times lower general corrosion rates (cr), as can easily be seen when evaluating a typical rate law curve [11] for the post transition Zircaloy corrosion regime:

$$
\begin{aligned}
& \mathrm{cr}=\mathrm{C}_{2} \exp \left(-\mathrm{Q}_{2} / \mathrm{RT}\right) \\
& \text { with } \mathrm{Q}_{2} / \mathrm{R}=14000 \mathrm{~K}^{-1} \\
& \mathrm{C}_{2}=\text { frequency factor, } \mathrm{T}=\text { temperature }
\end{aligned}
$$

This is the reason why today BWRs can still use the old BWR cladding variant Zircaloy-2 even with higher burn-up. Apart from the general corrosion, leading to a homogeneous corrosion layer, BWR fuel has however suffered from early-in-life, nodular, spot-like corrosion. When growing, these spots have interlinked and have led to strong patchy corrosion. The result led to premature corrosion-related tube withdrawal. The remedy against nodular corrosion was found in fabricating cladding with significantly reduced size distribution of the secondary phase particles. A late annealing step is applied during tube production, heating above the $\alpha \rightarrow \beta$ phase transformation temperature $\left(\sim 863{ }^{\circ} \mathrm{C}\right)$ followed by fast cooling, a so-called late $\beta$-quenching step. The dependency of nodular corrosion on the intermetallics size distribution can 


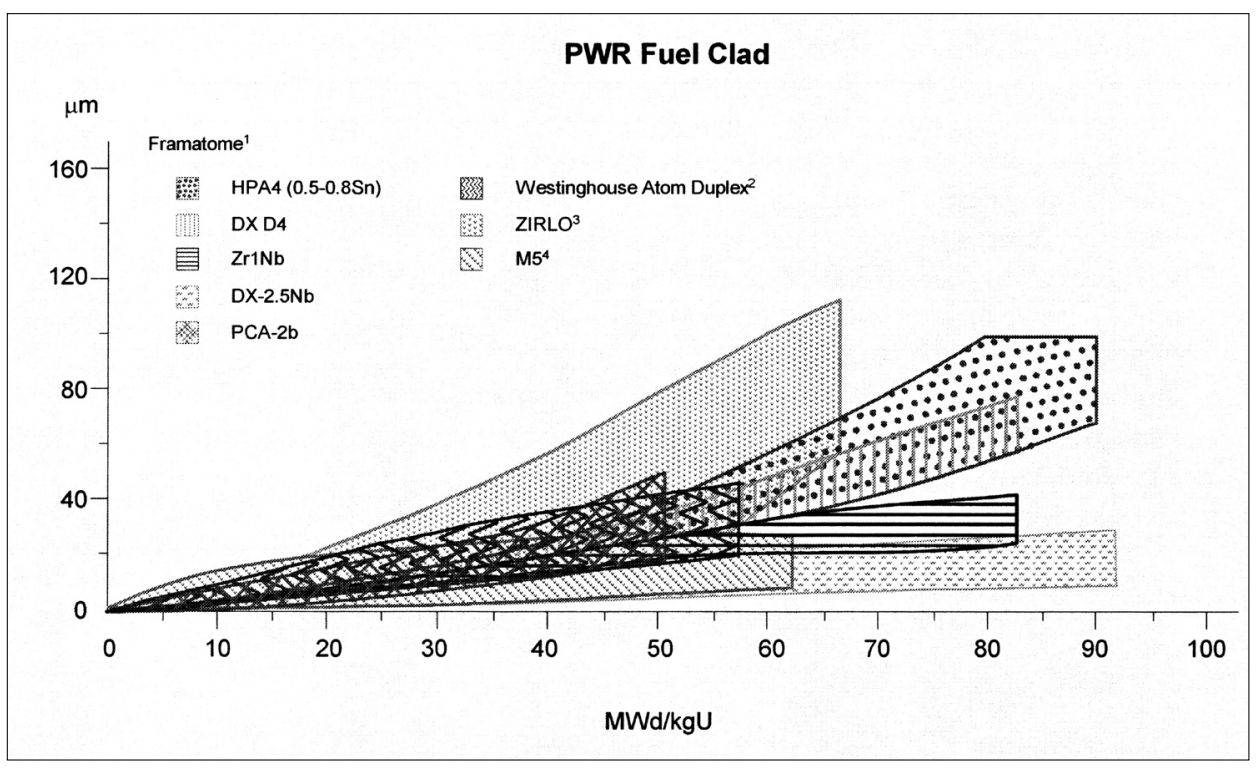

Fig. 6. Comparison of various advanced PWR fuel cladding materials. The Framatome claddings were all irradiated at Gösgen power station [6], Courtesy of ANT International, Surahammar, Sweden.

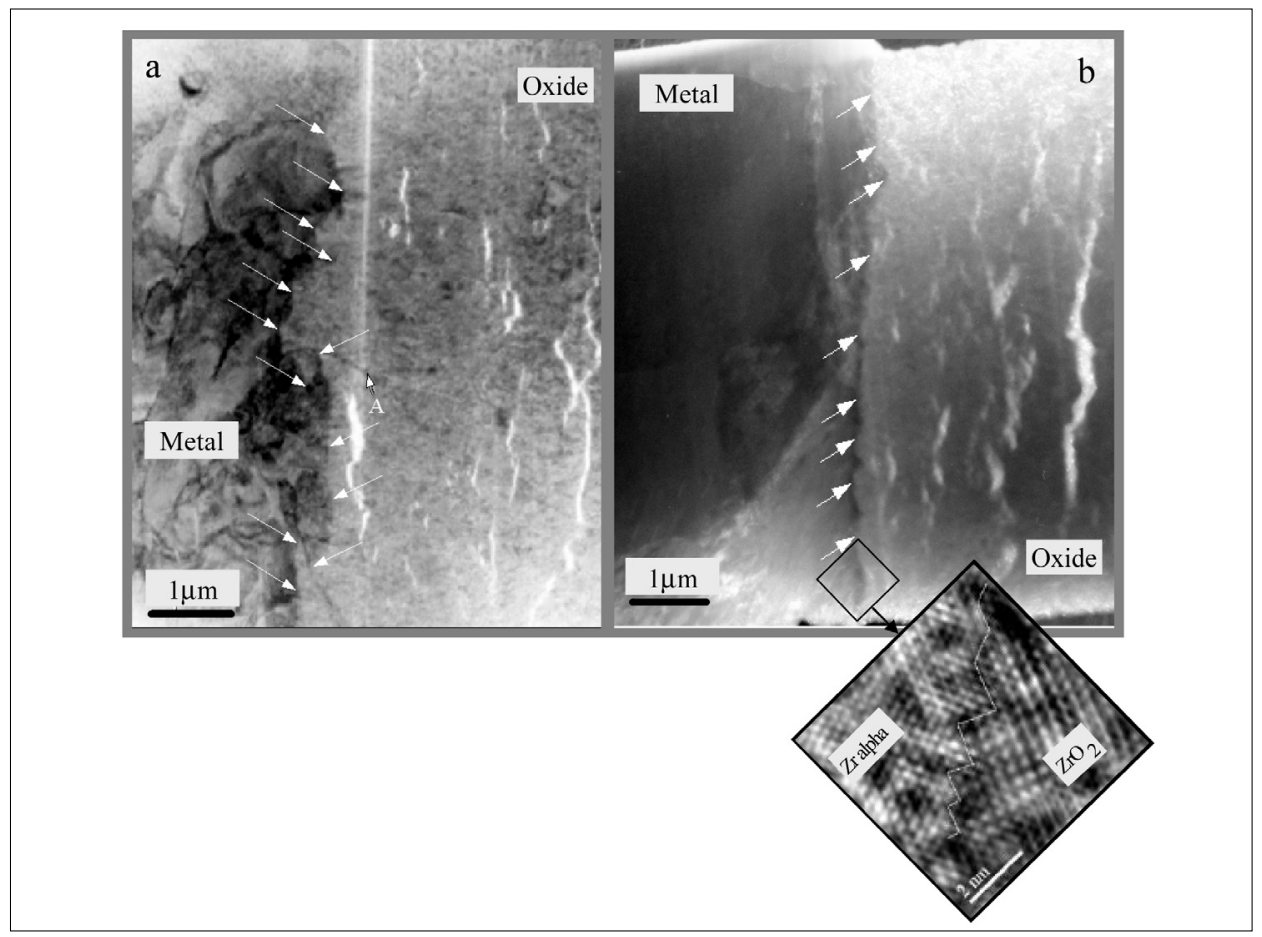

Fig. 7. Comparison of oxide-metal interface of two irradiated claddings which strongly differ in corrosion rate. The analysis was performed at PSI by transmission electron microscopy. The more corrosion resistant cladding (a) shows a corrugated interface, possibly reducing the oxide compressive stress level [10].

nicely be seen in Fig. 8 [12]. The mechanistic reason however for the occurrence or absence of nodular corrosion is still pretty vague. It is a fact that the process requires oxidizing water conditions which are absent in PWRs. The intermetallic precipitates of the alloy, which survive to a certain depth within the oxide layer before they are also oxidized, seem to play their role either in electron transport or in break down of the protective, dense innermost oxide layer. In BWR fuel cladding however, going towards too small secondary phase particles to omit effect on cladding behaviour although the
Water chemistry has quite a significant

\section{Influence of Water Chemistry on Cladding Corrosion}

concentrations of reactor water impurities are extremely low. But as shown in the water chemistry papers in this issue, these small concentrations, due to the enormous water throughput, can lead to significant annual loads of corrosion products of iron and nickel onto the large fuel core surface. In order to achieve low corrosion rates and to re-precipitate soluble metallic ionic concentrations at the cooler circuitry surfaces away from the fuel core, a $\mathrm{pH}(\sim 7.3$ at temperature) is selected with the highest (temperature-dependant) Fe solubility at the hotter fuel surfaces compared to the outer circuitry (steam generators for PWRs or recirculation lines for BWRs). Nevertheless as chemical additions of $\mathrm{Li}, \mathrm{B}$, and $\mathrm{Zn}$ are applied in PWRs and Zn, sometimes Fe, and noble metals ( $\mathrm{Pt}$ and $\mathrm{Rh}$ ) are added to BWR water, there are sometimes new unexpected fuel cladding corrosion phenomena encountered, presently some of the BWR plants in the United States demonstrate high amounts of surface precipitates. One such problem also arose at KKL-Leibstadt where at some time the fuel showed excessive corrosion at the spacer regions. The spacers contain Inconel hold-down springs and the excessive corrosion was probably linked to an electrochemical effect, a process however which could not be reproduced under autoclave conditions out-of-pile. The phenomenon at KKL could be suppressed by reducing the $\mathrm{Ni} / \mathrm{Fe}$ ratio in the reactor water, adding $\mathrm{Fe}$ concentrations in the $\mathrm{ppb}$ range.

\section{Cladding Mechanical Behaviour during Irradiation and Hydriding}

The irradiation damage leads to embrittlement and loss of ductility at $300{ }^{\circ} \mathrm{C}$ as shown in Fig. 9. When heating the cladding (under hypothetical accident condition) far beyond $300{ }^{\circ} \mathrm{C}$, the irradiation defects heal out and the cladding behaves in a ductile manner. At $800-1000{ }^{\circ} \mathrm{C}$ it can even balloon and break up when the internal xenon and krypton fission gas and helium pressure overbalance significantly the system pressure (which can occur under loss of coolant conditions). So the embrittlement at 300 ${ }^{\circ} \mathrm{C}$ is not primarily a safety concern under operation and even under hypothetical accident conditions. It is rather of a mechanical fuel handling issue after unloading at room temperature. The cladding is therefore requested to have at least a remaining ductility of $1 \%$ plastic strain when unloaded from the reactor core.

The mentioned $1 \%$ plastic strain criterion has to be fulfilled by high burn-up modern fuel. It can be hampered if hydrides, which form during hydrogen pick up in the cladding, precipitate in an unfavourable radial direction. This again can be omitted by 


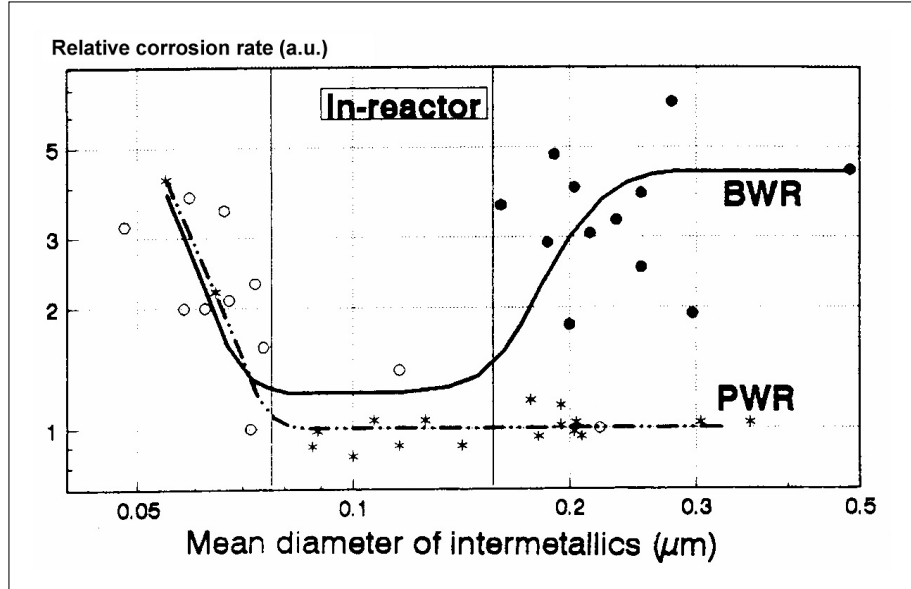

Fig. 8. Relative in reactor corrosion rate of BWR and PWR claddings in relation to the size distribution of the secondary phase intermetallic particles (SPPs). Too large SPPs lead to early in life nodular corrosion in BWRs, while too small SPPs are dissolved during irradiation and lead to late-in-life corrosion enhancement in BWRs and PWRs [12]. Courtesy of ASTM, West Conshohocken PA, USA.

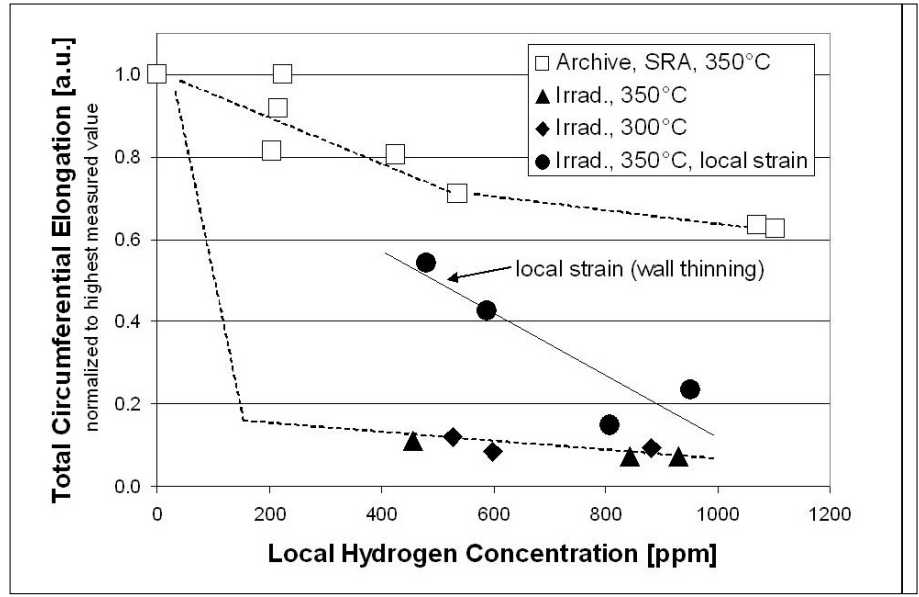

Fig. 9. Total circumferential elongation (rel.) measured at PSI by burst testing of unirradiated and irradiated cladding in function of cladding hydrogen concentration. The irradiation embrittlement dominates the hydrogen effect. If local wall thinning is considered, the remaining ductility after irradiation and hydriding still lies at $10-50 \%$ of the original ductility. the afore-mentioned texture orientation of the $<0001>$ plane of the hexagonal zirconium crystals being slightly off the radial axis as indicated in Fig. 2. The hydride embrittlement effect is more important at room temperature, as hydrides become ductile at higher temperature and dissolve as the solubility limit increases.

While the embrittlement and remaining ductility give an indication about maximal mechanical loads which can be withstood, they bear no information about a possible fracturing process, crack resistance, and fracture growth speed. Such tests are now being evaluated at PSI and other labs worldwide, although the geometries of the cladding tubes do not allow the application of classical fracture mechanics tests.

\section{Conclusions and Outlook}

Despite the demanding conditions in light water reactors the defect statistics of fuel show only a few leaks for a million of fuel pins. However the fuel burn-up is being pushed to still higher values until the average core burn-up approaches the limits for fuel with a U-235 enrichment of 5\%. This value is at $65 \mathrm{MWd} / \mathrm{kg}$ for BWRs and $70 \mathrm{MWd} / \mathrm{kg}$ for PWRs. Whether the U-235 enrichment is also going to be pushed further up depends on the importance which nuclear energy production is going to play in the future. On technical grounds high burn-up tolerable cladding is today available and during the last few years the improvement steps are focusing on large grain $\mathrm{UO}_{2}$ fuel which will release less gaseous fission products into the fuel pin plenum. Research is also focusing on high burn-up fuel with its behaviour during hypothetical accidents [13].
Unexpected cladding damages could occur due to alterations in water chemistry. Further optimized water chemistries are sought for the best protection of core structural internals (mainly in BWRs) against stress corrosion cracking (see F. Sarott: 'Water Chemistry in BWRs' [14]). In the area of PWRs, water chemistry changes are expected towards higher $\mathrm{pH}$ regimes, for further reduction of general corrosion phenomena on stainless steel and Inconel surfaces. For all these steps care must be taken to move on with evolutional, small steps and thorough, careful system control.

Received: June 6, 2005

[1] IAEA-TECDOC-996, 'Waterside corrosion of zirconium alloys in nuclear power plants', IAEA, Vienna, 1998

[2] C. Lemaignan, A.T. Motta, 'Zirconium Alloys in Nuclear Applications', in 'Nuclear Materials', Chap. 7, Vol. 10B, Vol. Ed. B.R.T. Frost, in 'Material Science and Technology', Eds. R.W. Cahn, P. Haasen, E.J. Kramer, VCH Verlagsgesellschaft $\mathrm{mbH}$, Weinheim, Germany, 1994.

[3] E. Tenckhoff, 'A Review of Texture and Texture Formation in Zircaloy Tubing', Ed. D.G. Franklin, Proc. $5^{\text {th }}$ Int. Conf. on Zirconium in the Nuclear Industry, 1982 5-25.

[4] A. Strasser, D.O. Boyle, R. Yang, 'Reliability - The First Priority in Fuel Performance', Proc. ANS Int. Topical Mtg. on LWR Fuel Performance, West Palm Beach, 1994, 3-11.

[5] B. Cox, 'Mechanisms of Zirconium Alloy Corrosion in Nuclear Reactors', JCSE 2003, 6, 14.

[6] P. Rudling, 'Corrosion of zirconium alloys', IZNA-2 special topics report, ANT International $\mathrm{AB}$, Sweden, 2003.
[7] T. Motta, A. Yilmazbayhan, A. Robert, J. Comstock, G.P. Sabol, B. Lai, Z. Cai, JNM 2004, 324(1), 6-22.

[8] R.B. Adamson, 'Effects of neutron irradiation on microstructure and properties of Zircaloy', Ed. G.P. Sabol, G.D. Moan, Zirconium in the nuclear industry ASTM STP 1354, West Conshohocken, USA, 2000, p. 15.

[9] C. Lemaignan, 'Physical phenomena concerning corrosion under irradiation of $\mathrm{Zr}$ alloys', Ed. G.D. Moan, P. Rudling, Zirconium in the nuclear industry ASTM STP 1423, West Conshohocken, USA, 2002, p. 20.

[10] S. Abolhassani, R. Restani, T. Rebac, F. Gröschel, W. Hoffelner, G. Bart, W. Goll, F. Aeschbach, 'TEM Examinations of the Metal-Oxide Interface of Zirconium Based Alloys Irradiated in a Pressurized Water', Ed. B. Kammenzind, P. Rudling, Journal of ASTM International 12390, Stockholm, Sweden, 2005, 2, 6.

[11] K. Forsberg, M. Limbäck, A.R. Massih, 'A model for uniform Zircaloy clad corrosion in pressurized water reactors', Nucl. Eng. and Design 1995, 154(2), 157-168.

[12] F. Garzarolli, H. Stehle, E. Steinberg, 'Behaviour and properties of Zircaloys in power reactors', Ed. E.R. Bradley, G.P. Sabol, Zirconium in the nuclear industry ASTM STP 1295, West Conshohocken, USA, 1996, p. 12.

[13] M. Zimmermann, G. Bart, Chimia, 2005, 59, 950.

[14] F. Sarott, Chimia 2005, 59, 923. 